\title{
The Relationship between Self-efficacy and Writing Performance across Genders
}

\author{
Felor Hashemnejad \\ Dept. of ELT, Ahar Branch, Islamic Azad University, Ahar, Iran \\ Masoud Zoghi \\ Dept. of ELT, Ahar Branch, Islamic Azad University, Ahar, Iran \\ Davoud Amini \\ Dept. of TESOL, Urmia University, Iran
}

\begin{abstract}
The study examined the relationship between the learners' self-efficacy and their writing performance across genders. Specifically, this study investigated the self-efficacy and writing performance of Makoo and Marand EFL students majoring in Teaching English as a Foreign Language (TEFL). One hundred twenty learners, between ages 20-29, were chosen. Two instruments were used to collect data. At three different points in time, the participants were given writing assessments and also responded to the questionnaires on self-efficacy. The data were analyzed using Pearson's correlation statistic and independentsamples $t$-test. Results revealed that there was no significant relationship between male and female EFL students' self-efficacy and writing performance. It was also found that there was a significant positive relationship in self-efficacy between female and male EFL students. This study is expected to contribute to the related literature by shedding light on the relation of student self-efficacy and writing performance.
\end{abstract}

Index Terms - English as a foreign language, self-efficacy, writing performance, gender

\section{INTRODUCTION}

One of the four skills in language learning which more attention must be paid to is writing. It is the major tool by which learners show their knowledge in the target language (TL). However, it is a hard skill to learn and a demanding task as it requires a number of processes that should be performed simultaneously. As it seems, EFL learners should work hard to develop and improve their writing abilities.

One of the main tasks of language teachers is promoting students' cognitive, behavioral, and motivational engagement through enhancing students' self-efficacy. According to Bandura (1986) self-efficacy is learners' beliefs in their capability to succeed and acquire new information or complete a task or activity to an appointed level of performance. Bandura (1992) believed that there is a difference between students with high self-efficacy and those with low self-efficacy. The learners with high self-efficacy feel confident about finding the solution to a problem because the learners have created an idea to problem solving that has accomplished in the past. They believe that their own competency will better when they work more, the learners assign their success according to their own attempts and schemes and acknowledge that errors are a process of acquisition. However, low self-efficacious learners believe that they have innate low ability, choose less requesting tasks on which they will make few errors, and do not try hard because they believe that any attempt will reveal their own lack of ability.

Traditionally, the teaching of writing has put a lot of emphasis on the written product. Students' writing has typically been evaluated according to its form and presentation without concern for how they generated ideas. Teachers always need to discover a way to support students and encourage the unwilling writers. As is often discussed, self-efficacy plays an important role in the development of writing competence, as well. While most writing self-efficacy studies have been studied in Western countries, in the Iranian EFL context there is a lack of research about writing self-efficacy beliefs. In fact, there have been few studies that examined the relationship between self-efficacy and writing performance. Thus, it seems urgent to fill this research gap.

That said, the purpose of this study was twofold. First, it aimed to study the relationship between self-efficacy and writing performance of students learning English as a foreign language. Second, it intended to look into the self-efficacy and writing performance across male and female EFL students. In line with the purpose of the study, this investigation attempted to find appropriate answers to the following questions:

RQ\#1: Is there any relationship between male EFL students' self-efficacy and writing performance at three different administrations?

RQ\#2: Is there any relationship between female EFL students' self-efficacy and writing performance at three different administrations?

RQ\#3: Is there any significance difference in self-efficacy between female and male EFL students? 
RQ\#4: Is there any significance difference in writing performance between female and male EFL students?

Based on the above questions, four hypotheses of the study were stated as follows:

H1: There is a significant relationship between male EFL students' self-efficacy and writing performance at three different administrations.

H2: There is a significant relationship between female EFL students' self-efficacy and writing performance at three different administrations.

H3: There is a significance difference in self-efficacy between female and male EFL students.

H4: There is a significance difference in writing performance between female and male EFL students.

\section{LITERATURE REVIEW}

Perhaps most well-known for his development of the self-efficacy theory is Albert Bandura. Bandura (2006) believes that people are more probably to be confidently affected in related activities when they accept they have capacity of attaining a certain task. These beliefs influence the choices people make and the courses of action they pursue (Pajares, 1996).

\section{The Role of Self-Efficacy in Performance}

According to Bandura, 1994, the people who have self-efficacy beliefs decide how think, feel and act. So if individual believe that they can actually form the wanted outcome, they will have the motivation and encouragement to develop a definite action. When people select to take part in activities, these self-efficacy beliefs influence them, these beliefs also affect the attempt that they extend and how they bear when encountered with troubles. (Bandura, 1986; Pajares, 1997; Schunk, 1991). In the past research, among all the motivational constructs, perceived self-efficacy was usually discovered to have the strongest predicting power, over individuals' writing performance; such discovering support the claim made by Bandura based on social cognitive theory that self-efficacy has a main function in predicting writing performance. For example, Rankin, Bruning and Timme (1994), searched to explore the relationship between self-efficacy, result expectancy, ascriptions for good spelling, previous accomplishments, and spelling performance as measured by a 30-item grade level spelling test. This study included 687 public school students in grades 4, 7, and 10, and discovered that self-efficacy at all grade levels was the strongest predictor of performance. Pajares and Valiante (2001) investigated on 218 fifth grade students. They wanted to know the influence of the influence of writing selfefficacy, writing ability, perceived usefulness of writing, and writing apprehension on the essay-writing performance. They found that self-efficacy beliefs made an independent constituent to the expectation of performance despite the expected strong outcome of writing ability.

2. Gender and Self-Efficacy:

Gender is something we born with, not something we have, but something we do (West \& Zimmerman, 1987) something we perform (Butter, 1990). Regarding writing self-efficacy and performance, gender differences are particularly common (Hansen, 2009). Previous researchers about school children have revealed that boys report lower writing self-efficacy than girls, despite the fact that boys tend to over-estimate their writing ability. (Pajares, 2002). On writing task the girls consistently out-performed the boys in studied with the girls and boys had same levels of selfefficacy beliefs. (Wigfield, Eccles, \& Pintrich, 1996). Pajares and Valiante (2001) suggested that these gender differences were tied with task orientation: in other words, writing is a female area when higher female self-efficacy is linked in the stereotypical view. In writing self-efficacy gender differences become vague when task orientation was controlled. (Pajares \& Valiante, 2001; Pajares, Valiante, \& Cheong, 2007). Greene (1999) found that in writing selfefficacy there are not gender differences among college freshmen but in performance there is a difference, in his study about composition the females gaining higher grade than the males. Such findings make the question of whether in gender, age is an unimportant factor in writing self-efficacy when the students enter to the university.

\section{Self-efficacy and writing}

Writing self-efficacy means to students' beliefs in their ability to perform written English task successfully. Such tasks include composition, correctly punctuating writing and creating grammatically correct samples of writing. At the end of school term, students writing skill and self-efficacy predicted. Overall, students who evaluate themselves as poor writers tend to perform being reluctant to engage in writing works and making brief or incomplete pieces of writing while students with higher writing self-efficacy have been found to complete writing tasks at a higher standard. (Bandura, 1994). In both areas of composition and self-efficacy, researchers have discovered enormous interest in writing self-efficacy, and they have worked the relationship between writing self-belief and writing final result in universities; their findings displayed a strong relationship between them (Bruning \& Horn, 2000; Pajares, 2003; Pajares \& Johnson, 1996). Pajares and Valiante (2001) examined on 218 fifth grade students about the influence of writing selfefficacy, writing ability, perceived usefulness of writing, and writing apprehension on the essay-writing performance. They discovered that despite the anticipated strong effect of writing ability, self-efficacy beliefs made an independent part to the prediction of performance.

4. Limitations and Delimitation of the Study

Several limitations of the study deserve discussion. Similar to other self-efficacy studies, it is really hard to observe the self-efficacy of people as they are not observable directly. Another limitation of this study is related to the quality of the questionnaire used. In this regard, Farhady (1999) stated that "they [questionnaires] take away the freedom with 
which respondents can answer the questions. In fact, we have limitation to choice the responses. The generalizability of the results can also be a limitation of the study. The participants of this survey were 120 students from Islamic Azad University of Makoo and Marand. So, the results can be generalized only to this group of learners. Younger learners maybe have lower self-efficacy than older ones and this limitation was out of researcher's control. Time was another delimitation of this current study; the researcher had to give a questionnaire at one week interval. It was possible the learner received the questionnaire once a month, so the learner's self-efficacy maybe different from that ones

\section{Methodology}

\section{Design of the Study}

This study was regarded as a correlational research investigation. There were three variables in this study, one of which is the academic self-efficacy of the TEFL candidates and the other ones were their writing performance and gender.

\section{Participants}

In this study, the participants were chosen from Islamic Azad University of Makoo and Marand. At the time of conducting this research, they were majoring in Teaching English as a Foreign Language (TEFL). Out of 200 individuals, 120 participants (56 males and 64 females) were chosen as the ultimate candidates for the research. The basis of the choice was a standardized English proficiency test of TOEFL. There were 95 items in the test. It was administered to determine the homogeneity of the participants. Then, those candidates who scored one standard deviation above and below the mean were conceived of as being at the intermediate level and selected as the plausible subjects. The age of participants ranged from 20 to 29 . There was no age limitation since we observed an age disparity among the participants.

These participants were selected through the purposive sampling as long as they fit the requirements of the research effort and the researcher desires, of course, through the filter of an English proficiency test.

\section{Instruments}

For the purpose of the current study, the following instruments were used:

A. Sherer et al.'s General Self-Efficacy Scale (SGSES)

B. Three IELTS writing tasks

General Self-Efficacy Questionnaire: The instrument used in this study was Sherer et al.'s General Self-Efficacy Scale (SGSES), designed by Sherer, Maddux, Mercandante, Prentice-Dunn, Jacobs, and Rogers (1982). It was used to assess the participants' self-efficacy (See Appendix A). SGSES is a self-report questionnaire and consists of 17 statements. The scoring method for general self-efficacy is a matter of one to five points awarded (totally disagree $=1$ to totally agree=5) based on Likert scale. In general, the questionnaire included 17 sections which scores increases for the sections 3, 8, 9, 13, 15 from left to right and others from right to left; higher scores indicating higher self-efficacy.

Writing Test: The writing test was selected from the IELTS test. The results were studied according to a nine-band scale. Each overall band scale point out a descriptive statement which tells a summary of the English language ability of a student categorized at that level. These levels go as follows (for more details, see www.ielts.org): these guidelines appear in Appendix B.

\section{Data Collection Procedure}

Each participant performed composition (writing test) and filled out a questionnaire (SGSES) on 3 occasions at one week intervals. The SGSES was distributed among participants after two days of participant selection. To find out the relationship between self-efficacy and writing performance, the participants were required to fill out the SGSES. The questionnaire consists of 17-item. Completing the questionnaire took 20 minutes. The participants had to fill out this questionnaire for 3 times at one week interval. The reason for this timed filling-out was to ensure the consistency of participants' scores over time. Then, with a one week interval, a test of writing ability based on IELTS writing topics was given to the participants. Three topics were given to the participants and they were asked to select one. The writing tests took 40 minutes, which required participants to write at least 250 words. Their writing test was scored by three raters based on the guidelines available on the IELTS official website.

\section{Variables of the Study}

As the current research is a correlation study, the main focus is on the three variables of writing performance, selfefficacy, and gender. The writing performance was considered as the dependent variable which includes the value of writing according to the content of the writing test. Gender was another variable which appeared as the moderator variable in terms of writing performance and self-efficacy. And finally, self-efficacy was considered as the independent variable. The age of the learners was not controlled as a variable.

\section{DATA ANALYSis}

In the analysis of the obtained data, the Statistical Package for Social Sciences (SPSS Version 16) software was used. First, descriptive statistics was calculated. Then, Pearson product-moment correlation was employed to determine the association between participants' English writing performance and self-efficacy beliefs. Also, the effect of gender on participants' writing performance and self-efficacy beliefs was determined by conducting t-tests. 
The relationship between male EFL students' self-efficacy and writing performance was examined using Pearson product-moment correlation coefficient. As shown in Table 4. 1, at three different points in time, no significant relationship was found between male EFL students' self-efficacy and writing performance.

(Time 1) $\mathrm{r}=.09, \mathrm{n}=56, \mathrm{p}=.49$; (Time 2) $\mathrm{r}=.00, \mathrm{n}=56, \mathrm{p}=.97$; and (Time 3) $\mathrm{r}=.13, \mathrm{n}=56, \mathrm{p}=.31$. Therefore, the first research hypothesis, H1: There is a significant relationship between male EFL students' self-efficacy and writing performance at three different administrations was rejected.

TABLE 1.

RESUlTS OF PEARSON's CORRELATION FOR MALE SELF-EFFICACY \& WRITING SCORES

\begin{tabular}{llll}
\hline & N & Pearson Correlation & Sig. (2-tailed) \\
\hline Male Self-efficacy*Writing (Time 1) & 56 & .093 & .497 \\
Male Self-efficacy*Writing (Time 2) & 56 & .004 & .974 \\
Male Self-efficacy*Writing (Time 3) & 56 & .136 & .317
\end{tabular}

Similarly, the relationship between female EFL students' self-efficacy and writing performance was examined using Pearson product-moment correlation coefficient. As shown in Table 4. 2, at three different points in time, no significant relationship was also found between female EFL students' self-efficacy and writing performance, $($ Time 1$) \mathrm{r}=-.00, \mathrm{n}=$ 64, $\mathrm{p}=.94$; (Time 2) $\mathrm{r}=.06, \mathrm{n}=64, \mathrm{p}=.58$; and (Time 3) $\mathrm{r}=.03, \mathrm{n}=64, \mathrm{p}=.79$. Therefore, the second research hypothesis, H2: There is a significant relationship between female EFL students' self-efficacy and writing performance at three different administrations, was rejected.

TABLE 2.

RESUltS OF PEARSON's CORRELATION FOR FEMALE SELF-EFFICACY \& WRITING SCORES

\begin{tabular}{llll}
\hline & N & Pearson Correlation & Sig. (2-tailed) \\
\hline Female Self-efficacy*Writing (Time 1) & 64 & -.008 & .947 \\
Female Self-efficacy*Writing (Time 2) & 64 & .069 & .587 \\
Female Self-efficacy*Writing (Time 3) & 64 & .034 & .790
\end{tabular}

To test the third and fourth research questions, an independent-samples t-test with an alpha level of .05 were used. As Table 4.3 indicates, there was no statistically significant difference between the self-efficacy scores of the male EFL students and the female EFL students $(\mathrm{M}=78.77, \mathrm{SD}=3.22)$ and the female EFL students $(\mathrm{M}=79.74, \mathrm{SD}=2.62), \mathrm{t}(118)$ $=-1.81, \mathrm{p}=.07$ (two-tailed). The results indicate that the third research hypothesis is rejected. Thus, it can be said that male and female EFL students' self-efficacy is at the same level for this sample.

TABLE 3.

INDEPENDENT-SAMPLES T-TEST FOR SELF-EFFICACY SCORES

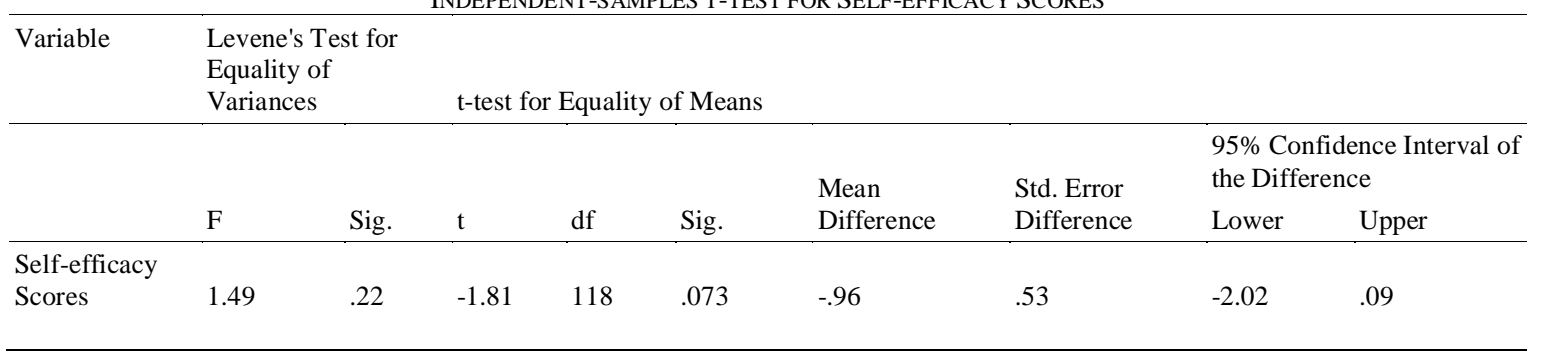

The final research question was about the difference in writing performance between female and male EFL students. As Table 4.4 indicates, there was no statistically significant difference between the self-efficacy scores of the male EFL students and the female EFL students $(M=5.93, \mathrm{SD}=1.76)$ and the female EFL students $(\mathrm{M}=6.07, \mathrm{SD}=1.87), \mathrm{t}(118)$ $=-.39, \mathrm{p}=.69$ (two-tailed). The results indicate that the fourth research hypothesis is rejected. Thus, it can be said that male and female EFL students' writing performance was also at the same level for this sample. Thus, it can be said that male and female EFL students' writing performance was also at the same level for this sample.

TABLE 4.

INDEPENDENT-SAMPLES T-TEST FOR WRITING SCORES

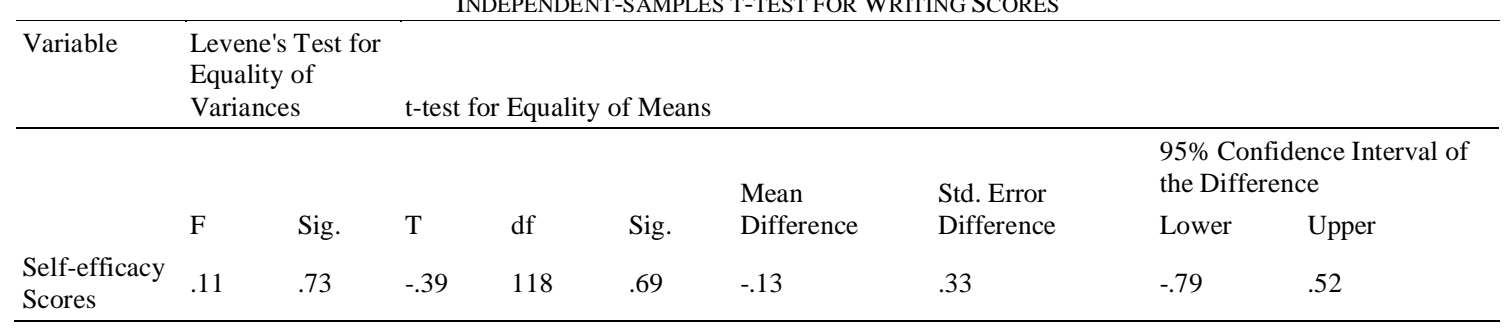

\section{DisCUSSION \& CONCLUSION}


As for the first question, it was aimed to examine the relationship between male EFL student's self-efficacy and writing performance at three different points in time. The finding showed that there was no significant relationship between male EFL students' self- efficacy and writing performance at three different points in time. Similarly, there was no significant relationship between female EFL students' self- efficacy and writing performance at three different points in time. Therefore, the second hypothesis was rejected. These findings are in contrast with researchers' findings that have revealed strong feeling in writing self-efficacy and they have investigated the relationship between writing self-belief and writing final result in universities; these findings shown a strong relationship between them (Pajares, F., 2000, Pajares, F. and M.J. Johnson, 1996, Pajares, F. and G. Valiente, 2001). The resulted displayed among all the motivational conceptions studies about writing performance, self-efficacy was usually found to have the strongest predicting power: such findings maintain the claim made by (Bandura, A., 1986) based on social cognitive theory, that self-efficacy behaves an essential function in predicting writing performance.

The third question was aimed to examine the differences in self-efficacy between female and male EFL students. The results showed there was no statistically difference between self-efficacy scores of the male EFL students and the female EFL students. Similarly, the fourth research question was indicated that there is a significance difference in writing performance between female and male EFL students. But the result revealed that there was not. These findings are in contrast with the research of Berry \& West, 1993; Bruning \& Horn, 2000; Pajares, Valiante, \& Cheong, 2007; Pintrich \& Schunk, 1996 that have reported that in writing self-efficacy gender differences dropped off with age, mainly due to falling in females' sense of self-efficacy. Gender differences are particularly common with regard to writing selfefficacy and performance (Hansen, 2009).

This study gave further evidence to support Pajares's statement (2000), who claims that the inner procedures of learners and the beliefs they grasp about their capabilities must be given due attention, since they might contribute to success or failure in school. We believe that this study contributes to the understanding of students' self-efficacy; this information should enable educators to develop innovative teaching materials taking account of these findings and upgrade their pedagogical practices. L2 learners also need to be helped to develop substantive knowledge of the writing process and to be trained in effective writing strategies. Such measures could increase learners' writing self- efficacy and benefit them in the long run, as well as empowering them to go through wonderful, though subconscious, lifelong learning experiences.

\section{Pedagogical Implications of the Study}

From the findings of this study, two pedagogical implications have been suggested, which are (i) to highlight writing strategies in the teaching, and (ii) to put the students in groups with students of different background and gender. As found in this research, the self-efficacy levels of the answerers are high but this does not mean that they will always be at the high level. It is very important that this high level is kept. In order to guarantee this, teachers should always give encouragement to students to maintain their level and/or further increase their confidence level since level of selfefficacy depends on the difficulty level of a specific task. The higher the level of studies they are in, the more difficult and challenging their tasks will be. They will have to do more to create ideas, thus they have to be more critical and analytical in thinking. Learners get self-efficacy information from knowledge of others' performances through social comparisons (Shunk \& Meece, 2006). Students who detect similar peers learning a task may also make sure that they can learn it. As such, students should work in groups which consist of mixed gender, especially small groups so that they can learn better from each other. As gender distribution in the teaching profession keeps on to be prevailed by females, the percentage of female students is higher than male students. However, mixing the students with the opposite gender should not be a problem, since it is not necessary to have equal number of students from the same gender in a group.

\section{Suggestion for Future Research}

To put the discussion of this section in a nutshell, this study has the following implications for practitioners:

- Teachers should examine various ways to discover effective methods in reducing unconscious gender stereotyping.

- There are ways in which to influence students' views of writing so that it is perceived as valuable and relevant to both male and female perceptions.

- Teachers can explain and model gender self-beliefs amongst students to help them to recognize" feminine" expressive, and the "masculine" wish to succeed so that they are better able to draw on the potential contribution of both.

- The professional development implications of these findings for the teachers would a whole school approach to gender stereotyping help to reduce differences in achievement amongst boys and girls.

Appendix A. The Questionnaire for General Self-efFicacy 


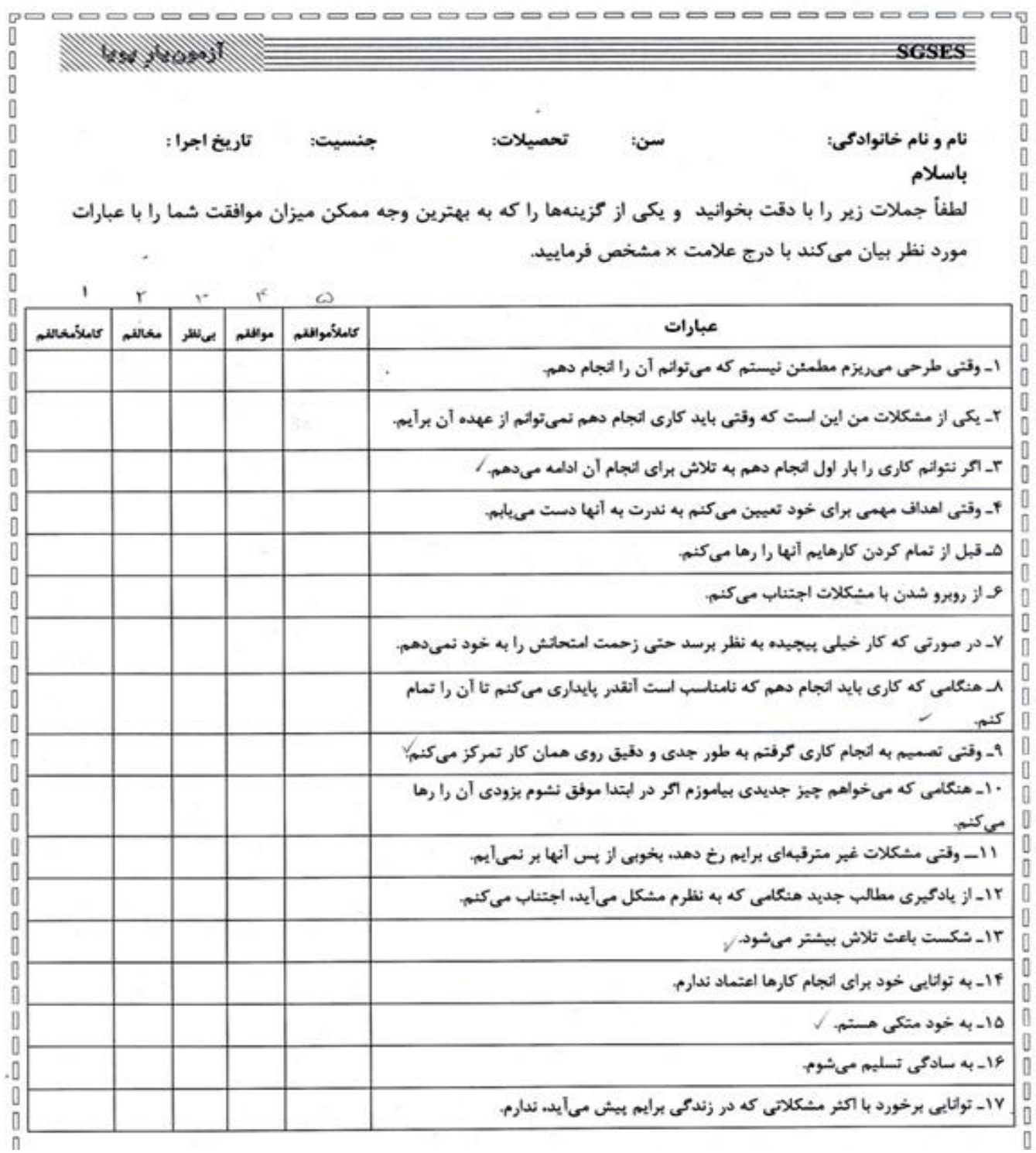

ApPendix B. Nine-BAND ScAle fOR Writing TEST FROM IELTs Test

\begin{tabular}{|l|l|l|}
\hline $\mathbf{9}$ & Expert user & Has fully operational command of the language: appropriate, accurate and fluent with complete understanding. \\
\hline $\mathbf{8}$ & Very good user & $\begin{array}{l}\text { Has fully operational command of the language with only occasional unsystematic inaccuracies and } \\
\text { inappropriate words. Misunderstandings may occur in unfamiliar situations. Handles complex detailed } \\
\text { argumentation well. }\end{array}$ \\
\hline $\mathbf{7}$ & Good user & $\begin{array}{l}\text { Has operational command of the language, though with occasional inaccuracies, inappropriate words and } \\
\text { misunderstandings in some situations. Generally handles complex language well and understands detailed } \\
\text { reasoning. }\end{array}$ \\
\hline $\mathbf{6}$ & Competent user & $\begin{array}{l}\text { Has generally effective command of the language despite some inaccuracies, inappropriate words and } \\
\text { misunderstandings. Can use and understand fairly complex language particularly in familiar situations. }\end{array}$ \\
\hline $\mathbf{5}$ & Modest user & $\begin{array}{l}\text { Has partial command of the language, coping with overall meaning in most situations, though is likely to make } \\
\text { many mistakes. Should be able to handle basic communication in own field. }\end{array}$ \\
\hline $\mathbf{3}$ & Limited user & $\begin{array}{l}\text { Basic competence is limited to familiar situations. Has frequent problems in understanding and expression. Is } \\
\text { not able to use complex language. }\end{array}$ \\
\hline $\mathbf{2}$ & Intermittent user & $\begin{array}{l}\text { Conveys and understands only general meaning in very familiar situations. Frequent breakdowns in } \\
\text { communication occur. }\end{array}$ \\
\hline $\mathbf{1}$ & Non user & $\begin{array}{l}\text { No real communication is possible except for the most basic information using isolated words or short formulae } \\
\text { in familiar situations and to meet immediate needs. Has great difficulty understanding spoken and written } \\
\text { English. }\end{array}$ \\
\hline $\mathbf{0}$ & Did not attempt the test & $\begin{array}{l}\text { Essentially has no ability to use the language beyond possibly a few isolated words. } \\
\text { No assessable information provided. }\end{array}$ \\
\hline
\end{tabular}

Three topics which were selected from IELTS test include:

1. It is generally accepted that families are not as close as they used to be. 


\section{A. Give some reasons why this change has happened and suggest how families could be brought closer together. \\ B. Include any relevant examples from your experience.}

2. Some people believe that children's leisure activities must be educational, otherwise they are a complete waste of time:

Do you agree or disagree?

Give reasons for your answer and include any relevant examples from your experience.

3. Some people think that it is better to educate boys and girls in separate schools. Others, however, believe that boys and girls benefit more from attending mixed schools. Discuss both views and give your opinions.

\section{REFERENCES}

[1] Bandura, A. (1986). Social foundations of thought and action: A social cognitive view. (pp. 34-54) Eaglewood Cliffs: Prentice Hall.

[2] Bandura, A. (1992). Self-efficacy mechanism in socio cognitive functioning. Paper presented at The American Educational Research Association annual meeting, San Francisco, CA. (67-90)

[3] Bandura, A. (1994). Self-Efficacy. In V. S. Ramachaudran (Ed.), Encyclopedia of human behavior (pp. 71-81). New York: Academic Press.

[4] Bandura, A. (2006a). Adolescent development from an agentic perspective. In F. Pajares\& T. Urdan (Eds.), Self-efficacy beliefs of adolescents (pp. 1-43). Greenwich,CT: Information Age Publishing.

[5] Berry, J. M., \& West, R. L., (1993). Cognitive self-efficacy in relation to personal mastery and goal setting across the life span. International Journal of Behavioral Development, 16, 351-379.

[6] Bruning, R., \& Horn, C. (2000).Developing motivation to write. Educational Psychologist, 35, $25-37$.

[7] Butter, J. (1990). Gender trouble feminism \& the subversion of identity. New York: Routledge.72-97.

[8] Greene, Gary L. (1999). Writing self-efficacy, gender, aptitude, and writing achievement among freshman university students. Unpublished doctoral dissertation. University of Alabama. DAI 60, 06A: p. 1932, Pub. No. AAG993551.

[9] Hansen, S. (2009). Gender Differences and Writing: Self-efficacy beliefs, attitudes, preferences and perceptions. Saarbrücken, Germany: Lambert Academic Publishing, 132-187

[10] Pajares, F. (1996). Role of self-efficacy beliefs in the mathematical problem-solving of gifted students. Contemporary Educational Psychology, 21,325-344.

[11] Pajares, F. (1997).Current directions in self-efficacy research. In M. Maehr\& P. R. Pintrich (Eds.), Advances in motivation and achievement (Vol. 10, pp. 17-49). Greenwich, CT: JAI Press.105-129.

[12] Pajares, F., (2000). Self-efficacy beliefs and current directions in self-efficacy resear Retrieved Sept, 2009 from http:// www.emory.edu/ EDUCATION/mfp/effpage.html. (32-56).

[13] Pajares, F. (2002). Overview of social cognitive theory and of self-efficacy. Retrieved September10, 2004, from www.emory.edu/education/mfp/eff.html. 69-94.

[14] Pajares, F. (2003). Self-efficacy beliefs, motivation, and achievement in writing: A review of the literature. Reading and Writing Quarterly, 19, 139-158. http://dx.doi.org/10.1080/10573560390143085.

[15] Pajares, F. and Johnson, M.J. (1996). Self-efficacy beliefs and the writing performance of entering high school students. Psychology in the Schools, 33, 163-179.

[16] Pajares, F. and Valiente, G. (2001). Response format in self-efficacy: Greater discrimination increases prediction. Counseling and Development, 33(4) (pp.35-43)

[17] Pajares, F., Valiante, G., \& Cheong, Y. F. (2007). Writing self-efficacy and its relation to gender, writing motivation, and writing competence: A developmental perspective. In P. Boscolo(Ed.), Writing and motivation (Studies in writing, vol. 19) (pp. 141-150). Bingley, England: Emerald Group Publishing.

[18] Pintrich, P. R., \&Schunk D. H. (1996).Motivation in education: Theory, research, and applications. (79-102) Englewood Cliffs, NJ: Merrill/Prentice Hall.

[19] Rankin, J., Bruning, R., \& Timme, V. (1994). The development of beliefs about spelling and their relationship to spelling performance. [Electronic version]. Applied Cognitive Psychology, (8)213-232.

[20] Schunk,D.H. (1991).Self-efficacy and academic motivation. Educational Psychologist, 26(3/4), 207-231.

[21] Shah, P.M. \& Mahmud, W.H.W \& Din, R \&Yusof, A \&Pardi, K.M. (2011). Self-efficacy in the writing of Malaysian ESL learners. World Applied Sciences Journal, 15, 8-11.

[22] Sherer, M, \& Madddux, J. E. (1982). The self-efficacy Scale: Construction and validation. Psychological Report, 51, 663-671.

[23] West, C. \& Zimmerman, D. (1987). Doing gender. Gender \& Society, 1,125-151.

[24] Wigfield, A., Eccles, J.S., \& Pintrich, P. (1996).Development between the ages of 11 and 25. In D.C. Berliner \& R.C. Calfee (Eds.), Handbook of educational psychology (pp. 148-185). New York: Simon \& Schuster/Macmillan.

Felor Hashemnejad, received her BA in English Translation at Tehran University (Center Branch) on 2001 and MA in TESL at Ahar University on 2014. Currently she is lecturer at many public schools and has experience about 9 years on teaching English subjects. Her research interests are performance on writing English language and self-efficacy.

Masoud Zoghi is assistant professor of TESL in the Dept. of ELT of Islamic Azad University, Ahar Branch in Iran. He earned his Ph. D. in TESL in 2009 from the National University of Malaysia. He has taught courses on research methodology, ESP, applied 
linguistics, and language testing at the M.A. and Ph.D. programs in ELT and General Linguistics. His current research and teaching focus includes research methodology in applied linguistics, psychology of language (esp. affective variables), cooperative learning, and reading comprehension.

Davoud Amini is an assistant professor of TESOL at Urmia University, Iran. Having been involved in EFL as an instructor and researcher for more than 15 years, he has published the textbook Taking Sides for topic-based conversation classes and presented and published papers in SLA in international conferences and journals. His academic areas of interest include affectivity in language learning, second language vocabulary acquisition and task-based language teaching. 